\title{
Evaluation of Proteolytic and Chitinolytic Activities of Indigenous Bacillus Species from Crab Shell Waste
}

\author{
Moh Dliyauddin $^{1^{*}}$, Tri Ardyati $^{2}$, Suharjono $^{2}$ \\ ${ }^{1}$ Master Program of Biology, Department of Biology, Faculty of Mathematics and Natural Sciences, University of \\ Brawijaya, Malang, Indonesia \\ ${ }^{2}$ Department of Biology, Faculty of Mathematicsand Natural Sciences, University of Brawijaya, Malang, Indonesia
}

\begin{abstract}
The increase of crab meat export activities in Indonesia leads to the accumulation of crab shell waste in a massive amount that can naturally degrade and causing bad odor. Naturally, microorganisms will degrade this waste through fermentation and enzymatic reaction, including protease and chitinase due to its high content of chitin and protein. Bacillus is the most potential bacteria to degrade crab shell waste, and indigenous Bacillus from this waste can increase the degradation rates. The aims of this study were to evaluate the proteolytic and chitinolytic activities of indigenous Bacillus species from crab shell waste. Bacillus cereus BP14 and Bacillus licheniformis CK20 as the chitinolytic bacteria, and Bacillus subtilis AP9 and Bacillus licheniformis AP5 as the proteolytic bacteria were isolated from crab shell waste and identified based on the $16 \mathrm{~S}$ rDNA sequences. The bacterial isolates were grown in skim milk broth for proteolytic characterization and colloidal chitin broth for chitinolytic characterization. The growth rates of each bacteria were determined through the growth curves. The enzymatic activities were determined based on the international standard for protease and chitinase enzyme activities together with growth curve sampling to determine the best incubation time for obtaining the highest enzymatic activities. From the shortest to the longest generation times of the Bacillus species obtained were $B$. subtilis AP9, B. licheniformis CK20, B. cereus BP14, and B. licheniformis AP5, respectively. The best incubation time for producing the highest enzymatic activity varied among species. However, the end of the logarithmic phase was similar. All of the Bacillus species obtained from this study exhibited chitinolytic and proteolytic activity. Therefore, it can be used as promising candidates of biodegradation agents inenhancing the degradation rates of crab shell wastes.
\end{abstract}

Keywords: Bacillus cereus, Bacillus licheniformis, Bacillus subtilis, chitinolytic, crab shell waste, proteolytic.

\section{INTRODUCTION}

The high demand for crab meat export in Indonesia causes the accumulation of crab shell wastes in the environment. One of the third most valuable marine commodities for export is blue swimming crab (BSC) or locally named as Rajungan crab (Portunuspelagicus) [1]. The effort to improve the BSC stock in Indonesia's fisheries are also developed in recent years so that the demand for its export can be fulfilled [2]. However, it is not followed by the improvement of waste management, including shell waste.

In Indonesia, the crab shell wastes are usually left on the open-terrain without processing. It will next naturally fermented by microorganisms and causing the bad odor, which pollutes the air in the environment. Thus, the research on the utilization of this waste in recent years is developed. Crab shell waste can be used to produce natural flavor powder [3], while this shell waste along with shrimp waste, can be used to produce $\mathrm{N}$-Acetylglucosamine by chitinolytic

\footnotetext{
*Correspondence address:

Moh Dliyauddin

Email : m.dliyauddin.md@gmail.com

Address : Dept. Biology, Brawijaya University, Malang 65145
}

soil Streptomyces sp. SJKP9 [4]. The utilization of this waste can improve the economic value of waste. However, due to the high cost of this processing management, it cannot be applied in Indonesia, especially in the marine fishery regions which the economy is middle to low and the technology is still poor.

Because of this reason, the possible effort to manage the crab shell wastes left in the fishery regions is by enhancing its degradation rates, so the time needed for the fermentation or degradation can be reduced. It can be done by inoculating microorganisms, especially the indigenous microorganism, which can produce protease and chitinase enzymes with high activity for crab shell wastes degradation. The crab shell waste can be used as the resource of chitin that can be utilized by microorganisms to grow and produce chitosan, including water-soluble chitosan [5], that can be further used in the biomedical and pharmaceutical application [6]. This study aimed to determine the proteolytic and chitinolytic activity of indigenous Bacillus species from crab shell wastes for obtaining promising candidate inoculums to enhance the degradation rates. 


\section{MATERIAL AND METHOD \\ Bacterial Isolates}

The bacterial isolates used in this study were Bacillus subtilis AP9 and B. licheniformis AP5 as proteolytic bacteria, while $B$. cereus BP14 and $B$. licheniformis CK20 as chitinolytic bacteria. All strains were isolated from blue swimming crab shell wastes using skim milk agar (casein 0.5\%, yeast extract $0.25 \%$, dextrose $0.1 \%$, skim milk $2.8 \%$, agar $1.5 \%$ ) [7] and colloidal chitin agar medium (bacto agar 1.5\%, yeast extract $0.5 \%$, $\mathrm{NH}_{4} \mathrm{Cl} 0.6 \%, \mathrm{Na}_{2} \mathrm{HPO}_{4} 0.6 \%, \mathrm{KH}_{2} \mathrm{PO}_{4} 0.3 \%, \mathrm{NaCl}$ $0.1 \%$, colloidal chitin $0.5 \%$.

\section{Growth Curves Preparation and Extracellular Enzymes Production}

The proteolytic bacterial strains were grown in skim milk broth (5 g. $\mathrm{L}^{-1}$ casein, $2.5 \mathrm{~g} . \mathrm{L}^{-1}$ yeast extract, 1 g.L L $^{-1}$ glucose, 1 g. L $^{-1}$ skim milk) [8] for $48 \mathrm{~h}$ of incubation in a rotary shaker incubator at room temperature. Meanwhile, the chitinolytic bacterial strains were grown in colloidal chitin broth for $48 \mathrm{~h}$ of incubation in rotary shaker incubator at room temperature. The sampling was conducted every $4 \mathrm{~h}$ by taking $3 \mathrm{~mL}$ of culture and storing it in the sterile tubes. It was then $1 \mathrm{~mL}$ used for enumerating the cell number using a haemocytometer to determine the generation times and growth phases. While the rest volume $(2 \mathrm{~mL})$ was centrifuged on 10.000 $\mathrm{rpm}$ at $4^{\circ} \mathrm{C}$ for $10 \mathrm{~min}$ and the pellets were discarded. The supernatant was assumed as the crude extracellular enzyme for both protease and chitinase. The crude extracellular enzymes were stored on the $4^{\circ} \mathrm{C}$ for further assay.

\section{Proteolytic and Chitinolytic Assay}

The crude enzymes were evaluated for the chitinolytic and proteolytic activities using standard methods. For proteolytic characterization, $1 \%$ casein solution was used as the substrate for protease activity that follows the standard procedure of Sigma [9] with few modifications. The crude was reacted with $1 \%$ casein solution and incubated at $37^{\circ} \mathrm{C}$ for $20 \mathrm{~min}$, and the reaction was stopped by the addition of $110 \mathrm{mM}$ Trichloroacetic acid (TCA), and the result was measured using UV-Vis spectrophotometer (Thermo Spectronic, New York, AS) at $540 \mathrm{~nm}$. The L-tyrosine standard curve was also prepared to determine the enzymatic activity $\left(\mathrm{U} \mathrm{mL}^{-1}\right)$. One unit of protease enzyme activity is defined as the amount of enzyme used to hydrolyze $1 \mathrm{\mu g}$ substrate per min [9].

For chitinolytic characterization, the crude enzyme was reacted with $1 \%$ colloidal chitin as a substrate and incubated at $30^{\circ} \mathrm{C}$ for $2 \mathrm{~h}$ [10]. The mixture was added with 3,5-dinitrosalicylic acid (DNS) reagent then heated at $100^{\circ} \mathrm{C}$ for $5 \mathrm{~min}$ before measured using UV-Vis spectrophotometer at $540 \mathrm{~nm}$. The Nacetylglucosamine standard curve was also prepared to determine the chitinolytic activity. One unit chitinase enzyme activity is assumed as the total of the enzyme for hydrolyzing $1 \mu \mathrm{g}$ substrate per $\mathrm{h}[10]$.

\section{Data analysis}

Data of growth were analyzed based on One Way Analysis of Variance (ANOVA). Data of proteolytic and chitinolytic activity were completed randomized design analyzed with Multivariate Analysis of Variance (MANOVA) using SPSS 16.0 application for windows with $\rho$ value $\leq 0.05$.

\section{RESULTS AND DISCUSSION}

\section{Growth curves and generation times}

A total of 20 proteolytic bacteria isolates and 22 chitinolytic bacteria isolates were successfully isolated from the samples and have the potential to produce protease and chitinase enzymes. The results showed that the growth phases of each potential bacteria strain were varied. However, all of the strains achieved their logarithmic phase ( $\log$ ) on $32 \mathrm{~h}$ of incubation time (Fig. 1) and then followed by a constant growth (also called stationary phase) until $48 \mathrm{~h}$. Based on the growth phases obtained from this study, the generation time of each Bacillus strain can be determined. The generation time from the fastest to slowest were $4.04 \mathrm{~h}, 6.77 \mathrm{~h}, 9.45 \mathrm{~h}$, and $11.88 \mathrm{~h}$ of $B$. subtilis AP9, B. licheniformis CK20, B. cereus $\mathrm{BP} 14$, and $B$. licheniformis AP5, respectively (Table 1).

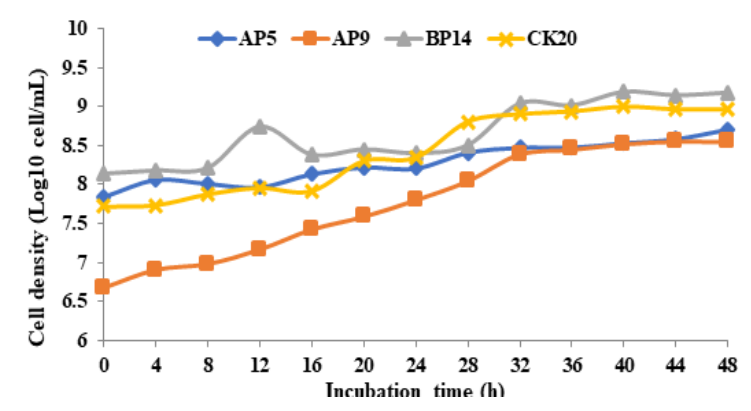

Figure 1. Growth curves of Bacillus species

Table 1. The generation times of Bacillus species

\begin{tabular}{clc}
\hline No. & \multicolumn{1}{c}{ Strains } & Generation time (h) \\
\hline 1. & Bacillus subtilis AP9 & 4.04 \\
2. & Bacillus licheniformisCK20 & 6.77 \\
3. & Bacillus cereus BP14 & 9.45 \\
4. & Bacillus licheniformisAP5 & 11.88 \\
\hline
\end{tabular}


In a normal condition with high nutritious medium content, Bacillus species generation time is 20-30 min [11], while in the lack of nutrients, the generation time is varied from 1-14 h. For example, B. amyloliquefaciens BSM-1 was $4.66 \mathrm{~h}$ and $B$. amyloliquefaciens BSM-2 was 5.25 $\mathrm{h}$ in medium supplemented with low-density polyethylene (LDPE) for biodegradation purpose [12]. The variation of generation times can be caused by the nutrition contents in the growth medium. Interestingly, the generation time of $B$. licheniformis CK20 and $B$. cereus BP14, which were grown in colloidal chitin broth medium that contained complex energy source (chitin), was faster than of $B$. licheniformis AP5 which was grown in skim milk broth medium. It indicated that $B$. licheniformis CK20 and B. cereus BP14 are potential candidates for crab shell wastes degradation due to their ability to degrade and utilize chitin in a short period. Microorganism requires nutrients to grow and maintain their life. The most microorganism will metabolize simple and complex sugars, including cellulose [13].

\section{Protease and Chitinase Activity of Bacillus Species}

Proteolytic and chitinolytic activities produced by each potential isolate have different variations at different incubation times (Fig. 2 and 3). Each potential isolate was able to produce proteolytic and chitinolytic enzymes simultaneously. Based on the results of the completed randomized design analysis, it was shown that proteolytic and chitinolytic activity significantly associated with incubation time and potential isolates $(p \leq 0.05)$.

The AP9 isolate had the highest activity (32.03 \pm 0.47 Unit. $\mathrm{mL}^{-1}$ ) compared to other isolates with an incubation time of 44 hours. Meanwhile, the highest protease activity of AP5 and BP14 isolates produced at 44 hours incubation time was $26.24 \pm 0.26$ Unit. $\mathrm{mL}^{-1}$ and $17.94 \pm 1.18$ Unit. $\mathrm{mL}^{-1}$ of enzymes per minute, respectively. The isolate of CK20 produced the highest protease activity by $24.62 \pm 1.05$ Unit. $\mathrm{mL}^{-1}$ of enzymes per minute at 48 hours of incubation.

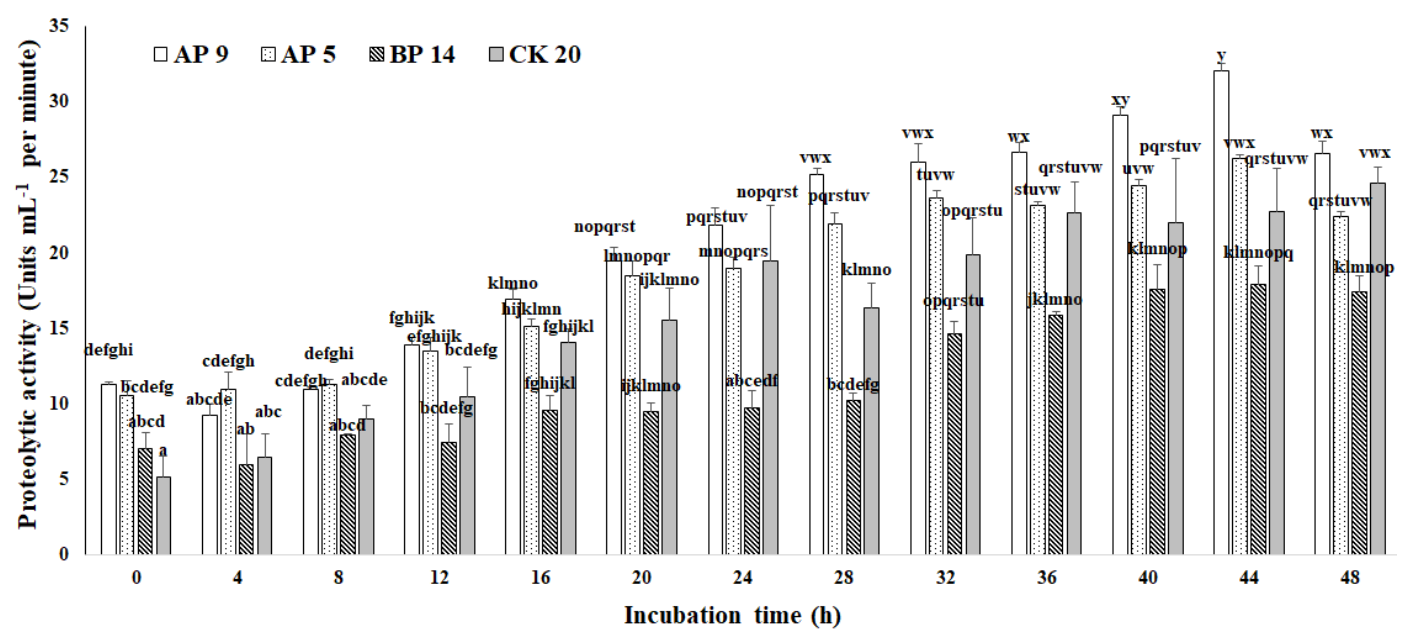

Figure 2. Proteolytic activity of potential isolates

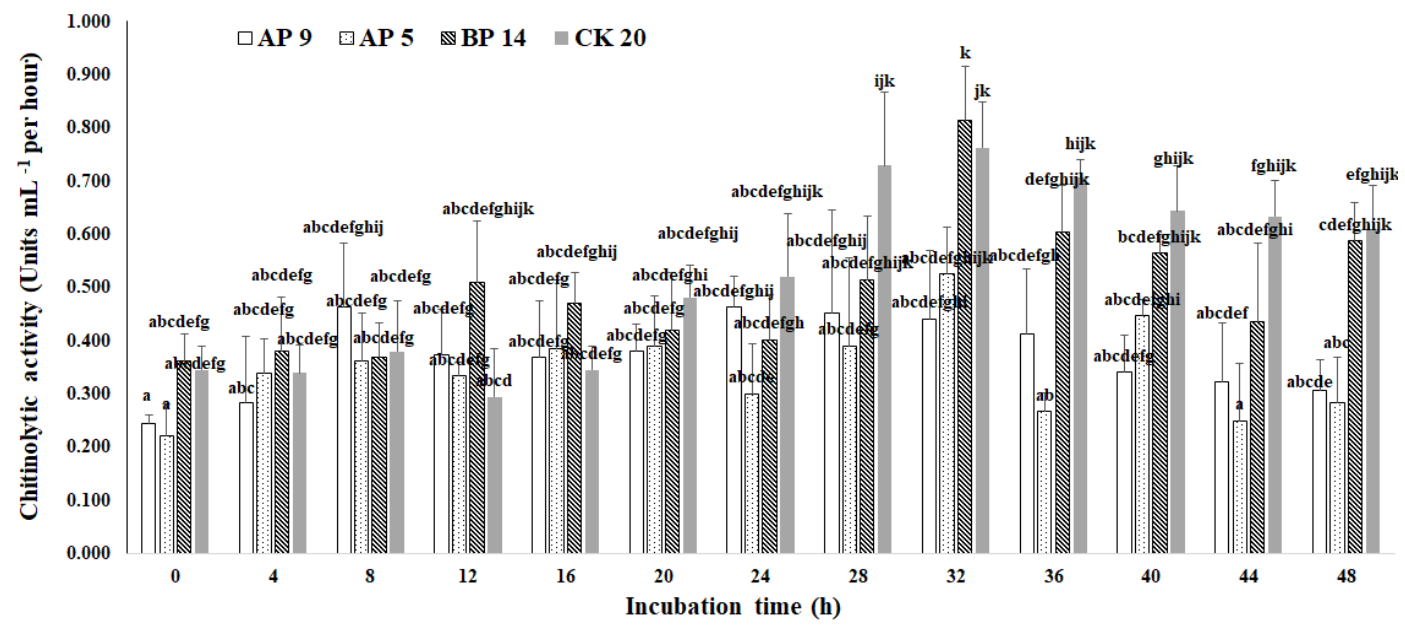

Figure 3. Chitinolytic activity of potential isolates 
The best chitinase activity was shown by BP14 isolate with the chitinolytic activity of $0.813 \pm$ 0.10 Unit. $\mathrm{mL}^{-1}$ of enzymes per hour at 32 hours of incubation compared to other potential isolates. The highest chitinase AP5 isolate activity produced at 32 hours incubation time was 0.526 \pm 0.08 Unit. $\mathrm{mL}^{-1}$ enzyme per hour, AP9 isolate the highest chitinase activity at 24 hours of incubation was $0.463 \pm 0.05$ Unit. $\mathrm{mL}^{-1}$ enzyme per hour, and CK20 isolate has the highest chitinase activity at 32 hours of incubation, amounting to $0.763 \pm 0.08$ Unit. $\mathrm{mL}^{-1}$ of enzymes per hour.

The highest enzymatic activities of both protease and chitinase were produced after 30 hours of incubation time, which is a phase of bacterial growth ending the logarithmic phase. In the stationary growth phase, the activity of the enzymes produced is the same and not significantly different due to small and equal cell growth $(p>0.05)$. It indicated the highest enzymatic activity of Bacillus strains used in this study was reached at the end of the log phase or at the initial of the stationary phase. Protease enzyme of bacteria is produced during the beginning of the stationary phase to the middle of the stationary phase [14]. Meanwhile, the chitinase enzyme is produced during the middle of the log phase to the stationary phase [15].

Protease enzymes are secreted in the early bacterial growth phase entering stationary until the middle of the stationary phase [14], while the chitinase enzyme is produced in the midlogarithmic phase until the stationary phase [15]. Protease and chitinase enzymes are the results of primary metabolites by bacteria, so the protease and chitinase enzymes produced are used by bacteria for their growth, which are supported by a large number of cells in the final logarithmic phase and the stationary phase of bacterial growth.

In this study, the optimization of $\mathrm{pH}$ and temperature to obtain the best enzymatic activity was not conducted yet. The proteolytic activity was categorized lower than the previous study. Bacillus subtilis can produce protease enzyme activity up to 243.28 Unit. $\mathrm{mL}^{-1}$ enzymes per $\mathrm{h}$ at $36 \mathrm{~h}$ incubation time on $45^{\circ} \mathrm{C}$ which has $\mathrm{pH} 10$ [16]. The chitinolytic activity was categorized higher than the previous study. Acinetobacter johnsonii PBK2 and $B$. amyloliquefaciens SA1.2 have an activity of 0.213 $\mathrm{mL}^{-1}$ units at $\mathrm{pH} 7$ at a temperature of $30^{\circ} \mathrm{C}$ [17]. Thus, it is necessary to determine the $\mathrm{pH}$ and temperature optimum conditions for obtaining the best enzymatic activity before applying it directly in the environment. By combining protease and chitinase enzymes, the degradation rates of chitin fibers and protein in crab shell wastes can be enhanced.

Bacillus species used in this study are potential candidates for biodegradation agents. In addition, these strains can be used to produce extracellular protease enzymes and chitinase for industrial-scale by degrading waste, which can improve the economic value. However, further study to optimization activity and characterization enzyme is still needed.

\section{CONCLUSION}

Indigenous Bacillus species from crab shell wastes were potential biodegradation agents due to their ability to produce high enzymatic activities, especially for the proteolytic and chitinolytic. This ability is still can be enhanced by the optimization for $\mathrm{pH}$ and temperature on their growth medium conditions.

\section{REFERENCES}

[1] Ghofar, A., S. Redjeki, H. Madduppa, M. Abbey, N. Tasunar. 2018. Inclusive blue swimming crab fishery management initiative in Betahwalang Demak, Indonesia. IOP Conference Series: Earth and Environmental Science. 1(116). 012068.

[2] Hamid, A., D.T. F. Lumban Batu, E. Riani, Y. Wardiatno. 2016. Reproductive biology of blue swimming crab (Portunuspelagicus Linnaeus, 1758) in Lasongko Bay, Southeast Sulawesi-Indonesia. AACL Bioflux. 9(5). 1053-1066.

[3] Mulyadi, A.F., J.M. Maligan, W. Wignyanto, R. Hermansyah. 2013. Organoleptic characteristics of natural flavour powder from waste of swimming blue crabs (Portunus pelagicus) processing: study on dextrin concentration and drying temperature. Jurnal Teknologi Pertanian. 14(3). 183-192.

[4] Jagadeeswari, S., M.D. Balakumaran, P. Vidya, P.T. Kalaichelvan, K.P. Selvam. 2012. Utilization of shrimp and crab wastes for the production of $\mathrm{N}$ - Acetylglucosamine by chitinolytic soil Streptomyces sp. SJKP9. Dyn. Biochem. Process Biotechnol. Mol. Biol. 6(2). 46-48.

[5] Lestari, P.I., I. Ulfin, H. Harmami, S. Suprapto, Y.L. Ni'mah. 2018. Water-soluble chitosan from waste swimming crab shell (Portunus pelagicus). AIP Conference Proceedings. 2049(1). 020085. 
[6] Sarbon, N.M., S. Sandanamsamy, S.F.S. Kamaruzaman, F. Ahmad. 2015. Chitosan extracted from mud crab (Scylla olivicea) shells: physicochemical and antioxidant properties. J. Food Sci. Technol. 52(7). 42664275.

[7] Tennalli, G., B. Udapudi, P. Naik. 2012. Isolation of proteolytic bacteria and characterization of their proteolytic activity. Int. J. Adv. Eng. Sci. Technol. 2(3). 185-192.

[8] Fulzele, R., E. Desa, A. Yadav, Y. Shouche, R. Bhadekar. 2011. Characterization of novel extracellular protease produced by marine bacterial isolate from the Indian Ocean. Braz. J. Microbiol. 42(4). 1364-1373.

[9] Cupp-Enyard, C. 2008. Sigma's non-specific protease activity assay - casein as a substrate. J. Vis. Exp. 17(19). 899. DOI: 10.3791/899.

[10] Zarei, M., S. Aminzadeh, H. Zolgharnein, A. Safahieh, M. Daliri, K.A. Noghabi. 2011. Characterization of a chitinase with antifungal activity from a native Serratia marcescens B4A. Braz. J. Microbiol. 42(3). 1017-1029.

[11] Choi, H.J., S.J. Kang, K.W. Hong. 2017. Comparison of NheA toxin production and doubling time between Bacillus cereus and Bacillus thuringiensis. Appl. Biol. Chem. 60(5). 545-551.

[12] Das, M.P., S. Kumar, 2013. A comparative study on microbial growth and substrate utilization kinetics. Int. J. Pharm. Technol. 12(5). 5567-5573.

[13] Sandle, T. 2016. Microbiological challenges to the pharmaceuticals and healthcare. Pharmaceutical Microbiology. Oxford: Woodhead Publishing. 281-294.

[14] Ibrahim, A.S.S., A.A. Al-Salamah, Y.B. Elbadawi, M.A. El-Tayeb, S.S.S. Ibrahim. 2015. Production of extracellular alkaline protease by new halotolerant alkaliphilic Bacillus sp. NPST-AK15 isolated from hyper saline soda lakes. Electron. Journal of Biotechnology. 18(3). 236-243.

[15] Kumar, A., N. Gupta, Laksh, S. Angural, M. Rana. 2017. Process optimization of extracellular chitinase production from Bacillus sp. isolated from fish waste dumping site. Eur. J. Pharm. Med. Res. 8(4). 474-480.

[16] Pant, G., A. Prakash, J.V.P. Pavani, S. Bera, G.V.N.S. Deviram, A. Kumar. 2015. Production, optimization and partial purification of protease from Bacillus subtilis. J. Taibah Univ. Sci. 9(1). 50-55.

[17] Setia, I.N., Suharjono. 2015. Chitinolytic assay and identification of bacteria isolated from shrimp waste based on 16S rDNA sequences. Adv. Microbiol. 5. 541-548. 